Article

\title{
The Synergism of Platinum-Gold Bimetallic Nanoconjugates Enhances 5-Fluorouracil Delivery In Vitro
}

\author{
Vareessh Maney and Moganavelli Singh *(1) \\ Nano-Gene and Drug Delivery Group, Discipline of Biochemistry, University of KwaZulu-Natal, \\ Private Bag X54001, Durban, South Africa \\ * Correspondence: singhm1@ukzn.ac.za; Tel.: +27-31-260-7170
}

Received: 7 July 2019; Accepted: 1 August 2019; Published: 1 September 2019

check for updates

\begin{abstract}
Nanoparticle application has significantly impacted the field of medicine. The need to develop novel drugs with higher therapeutic potential has stimulated the development of innovative delivery strategies to mitigate the potent side effects associated with known chemotherapeutic drugs. This paper describes the synthesis of platinum-gold bimetallic nanoparticles (PtAuBNps), their functionalisation with chitosan, and entrapment of the anticancer drug 5-fluorouracil (5-FU). All PtAuBNps and their drug nanocomposites were physico-chemically characterised, displaying desirable properties with regards to shape, size $(<120 \mathrm{~nm})$ and colloidal stability. 5-FU binding and loading capacities in PtAuBNps were found to be $90.17 \%$ and $22.56 \%$, respectively. In vitro cytotoxicity profiles determined using the MTT and SRB assays reflected up to $65 \%$ cell death in the MCF-7, HepG2 and Caco-2 cell lines. These nanocomposites exhibited excellent physiochemical attributes, high specificity towards cancer cells, with a $\mathrm{pH}$-sensitive drug release in a simulated acidic tumour microenvironment through zero-order release kinetics. In addition, they possessed the potential to traverse the mucosal lining facilitating oral drug administration. Overall, 5-FU encapsulation improved the bioavailability of the drug in cancer cells, with the promise of enhancing its therapeutic effect, biocompatibility and safety. These positive results highlight PtAuBNps as promising in vitro delivery systems and merits future in vivo research.
\end{abstract}

Keywords: 5-fluorouracil; bimetallic nanoparticles; cancer; gold; platinum; pH-responsive

\section{Introduction}

Cancer, the unrestrained proliferation of dysfunctional cells, is a leading cause of mortality worldwide. Several efforts have been made to advance treatment regimens. However, the astounding complexity at cellular, genetic and epigenetic levels allow this menacing disease to show great diversity, to resist treatment, re-emerge and invade surrounding tissue. Some of the well-established treatment options include surgery, radiation, hormonal therapy, immunotherapy and hyperthermia [1]. Chemotherapy utilises therapeutic compounds either alone or in combination to thwart cellular proliferation in both solid tumours and haematological cancers.

5-FU is a hydrophilic, water soluble, antimetabolite drug that is used extensively in clinical chemotherapy for the treatment of breast, brain, liver, pancreatic and lung cancers [2]. It is often a stand-alone drug for treatment of colorectal cancers, and together with modulators such as leucovorin and oxaliplatin, is the most effective treatment for metastatically advanced colorectal cancers [3]. However, its clinical application has limitations, including dose dependent side effects, rapid metabolism in vivo, short half-life, non-uniform oral absorption, compromised tissue penetration and non-selective biodistribution [4]. To overcome these underlying predicaments, the incorporation of potent biological 
agents together with metal nanoparticle carriers is rapidly gaining momentum. The desirable inherent properties of nanomaterials hold great promise in the treatment of cancer. Their favourable size, shape and surface morphology are bringing the "magic bullet" concept envisioned by Paul Ehrlich into realisation. Nanotechnology provides a dynamic strategy to exploit pathophysiological tumour abnormalities, bypass tedious biological barriers, infiltrate deep into subcellular compartments, and deliver therapeutic agents to their pathological target site, thus improving their therapeutic efficiency $[5,6]$.

Of the multitude of framework materials envisioned to deliver drugs safely, AuNps and PtNps are promising, owing to their inert core, high atomic number and enhanced optical and structural properties. Moreover, they can be easily fabricated within a favourable biomedical size range to possess high colloidal stability giving them the advantage over other nanoparticulate systems [7]. Noble metals also possess the ability to absorb light or radio waves, which has generated novel non-invasive cancer therapy options including, photodynamic therapy (PDT) and radiotherapy, which can be utilised with chemotherapy for better eradication of tumour cells [8]. While AuNps are bio-inert, stable and relatively non-toxic in biological systems, PtNps possess chemotherapeutic and chemo-preventative properties $[9,10]$. These remarkable features have inspired research into the synthesis of hybrid PtAuBNps, imbued with properties of both metals, as well as novel properties through quantum confinement and synergism. The synergistic combination of noble metals has exhibited potential in nanomedicine, particularly in cancer therapy as drug delivery vehicles and theranostic agents [11]. Modern metallurgy on the nanoscale present unique features, including an enhanced band gap, surface chemistry, photoluminescence, electrical and magnetic properties that rival monometallic systems [12]. Furthermore, by embracing surface functionalisation paradigms, these modern platforms can be tailored to release their payloads through either passive and sustained drug release or active targeting for site-specific drug delivery.

Chitosan (CS), a polycationic biopolymer is an exceptionally popular stabilising agent in drug delivery, owing to its biodegradability, non-toxicity, mucoadhesiveness, feasibility and permeation enhancing effects [13]. In recent years, CSNps have emerged as promising carriers for sustained release preparations, to improve storage stability, solubility and prolong the half-life of anticancer drugs [14]. The ionic gelation reaction based on the electrostatic interaction between the amine group of chitosan and TPP is a facile and inexpensive way to form chitosan nanospheres endowed with its inherent characteristics [15]. The entangled polymeric framework provides a large surface area to volume ratio for the encapsulation of PtAuBNps and 5-FU. In addition, the flexible nature of the cross-linked framework allows the tailored release of drugs through $\mathrm{pH}$-induced gel-sol transitioning [16,17]. The addition of the PEG bearing emulsifier Tween 80 stabilises and confers the CS nanocomposites with fusogenic properties similar to dioleoylphosphatidylethanolamine (DOPE) [18]. This is essential for successful endolysosomal escape, and maximising the transport of 5-FU into the nucleus. It is anticipated that precisely engineered target activated delivery systems, instilled with good physiochemical characteristics, will bring about site-specific cancer targeting through apoptosis induction.

In this study, PtAuBNps and 5-FU were enclosed in an entangled CS framework to support: (1) favourable physiochemistry; (2) high mucoadhesive propensity; (3) pH-responsive release; and (4) site-specific induced toxicity in vitro (Figure 1). Currently, there is a dearth of scientific knowledge regarding the cytotoxicity, delivery and therapeutic capabilities of PtAuBNps. To the best of our knowledge, this is the first reported delivery of 5-FU with PtAuBNps, with the delivery of doxorubicin being reported previously [17]. 


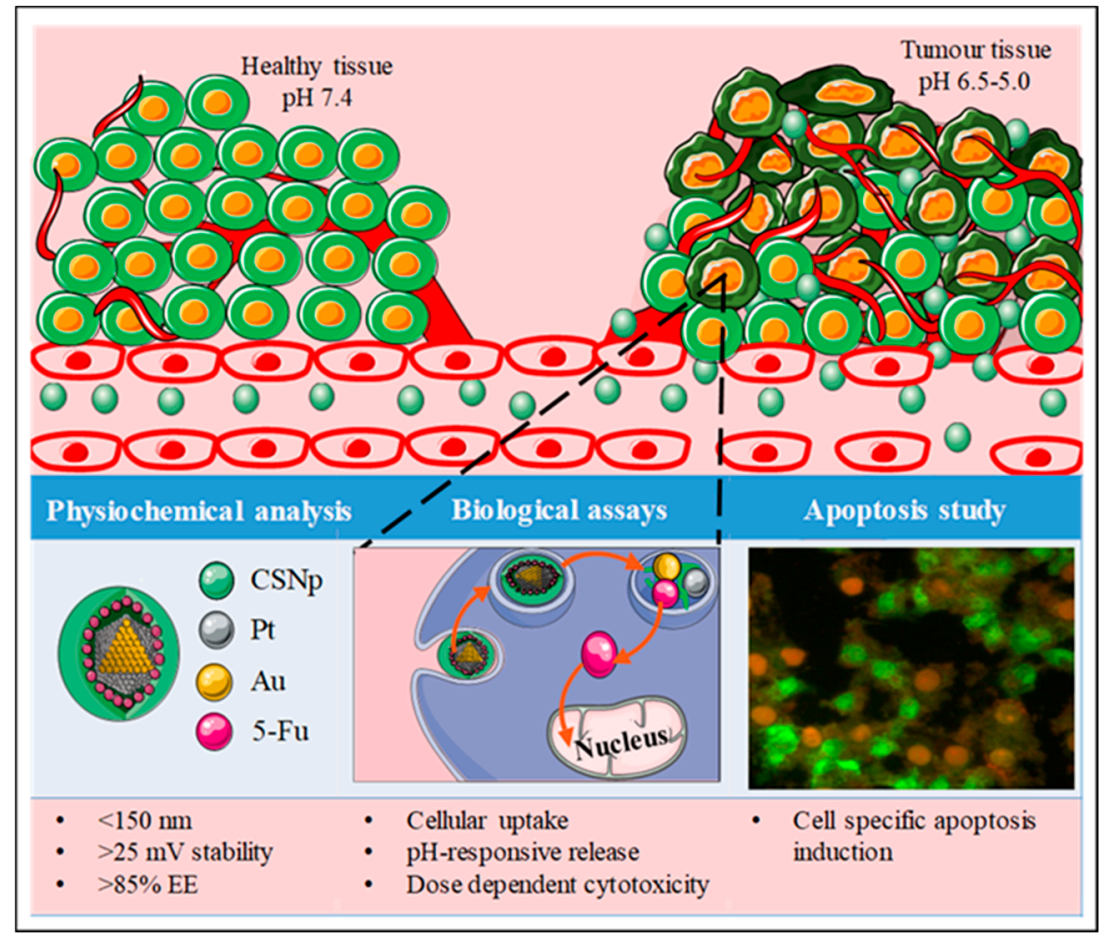

Figure 1. Schematic illustration of 5-fluorouracil encapsulated platinum-gold/chitosan bimetallic nanoparticles for systemic delivery and release to cancer cells leading to cytotoxic responses and apoptosis induction.

\section{Materials and Methods}

\subsection{Materials}

Hydrogen hexachloroplatinate(IV) hexahydrate $\left(\mathrm{H}_{2} \mathrm{PtCl}_{6} \cdot 6 \mathrm{H}_{2} \mathrm{O}, \mathrm{Mw}: 517.90 \mathrm{~g} / \mathrm{mol}\right)$, gold (III) chloride trihydrate $\left(\mathrm{HAuCL}_{4} \cdot 3 \mathrm{H}_{2} \mathrm{O}, \mathrm{Mw}: 393.83 \mathrm{~g} / \mathrm{mol}\right)$, polyvinylpyrrolidone (PVP, Mw 40,000), sodium borohydride $\left(\mathrm{NaBH}_{4}, \mathrm{Mw}: 37.83 \mathrm{~g} / \mathrm{mol}\right)$, sodium triphosphate $\left(\mathrm{Na}_{5} \mathrm{P}_{3} \mathrm{O}_{10}, \mathrm{Mw}: 367.86 \mathrm{~g} \mathrm{~mol}^{-1}\right)$, porcine mucin, sulphorhodamine $\mathrm{B}$ (SRB Dye, $\mathrm{C}_{27} \mathrm{H}_{30} \mathrm{~N}_{2} \mathrm{O}_{7} \mathrm{~S}_{2}$, Mw: $558.67 \mathrm{~g} / \mathrm{mol}$ ), 5-fluorouracil (5-FU, $\mathrm{C}_{4} \mathrm{H}_{3} \mathrm{FN}_{2} \mathrm{O}_{2}$, Mw: $130.1 \mathrm{~g} / \mathrm{mol}$ ), polysorbate 80 (Tween 80, Mw:1310 g/mol, $\mathrm{C}_{64} \mathrm{H}_{124} \mathrm{O}_{26}$ ), acridine orange hemi (zinc chloride) salt [3,6-Bis(dimethylamino) acridine hydrochloride zinc chloride double salt] $\left(\mathrm{C}_{17} \mathrm{H}_{19} \mathrm{~N}_{3}, \mathrm{Mw}\right.$ : $\left.265.36 \mathrm{~g} / \mathrm{mol}\right)$, chitosan (75\% deacetylation) and dialysis tubing (MWCO 12,000 Daltons) were purchased from Sigma-Aldrich (St. Louis, MO, USA). Ethidium bromide, glacial acetic acid, dimethyl sulphoxide (DMSO), 3-[(4,5-dimethylthiazol-2-yl)-2,5-diphenyl-2H-tetrazolium bromide] (MTT) and phosphate buffered saline tablets (PBS (140 mM NaCl, $10 \mathrm{mM}$ phosphate buffer, and $3 \mathrm{mM} \mathrm{KCl}$ )) were sourced from Merck (Darmstadt, Germany). Eagle's Minimum Essential Medium (EMEM) with L-glutamine $(4.5 \mathrm{~g} / \mathrm{L})$, trypsin-versene-EDTA mixture and antibiotic mixture [penicillin $(10,000 \mathrm{U} / \mathrm{mL})$, streptomycin $(10,000 \mu \mathrm{g} / \mathrm{mL}$, and amphotericin B $(25 \mu \mathrm{g} / \mathrm{mL})]$ were purchased from Lonza BioWhittaker (Verviers, Belgium). Sterile foetal bovine serum (FBS) was purchased from Hyclone GE Healthcare (South Logan, UT, USA). Human embryonic kidney cells (HEK293), breast adenocarcinoma (MCF-7), human epithelial colorectal adenocarcinoma cells (Caco-2), and human hepatocellular carcinoma cells (HepG2) was obtained from the ATCC (Pty) Ltd., Manassas, VA, USA. All sterile tissue culture plasticware were obtained from Corning Inc. (Corning, NY, USA). All chemical reagents were of analytical grade and were used without further purification. Ultrapure (18 MOhm) water (Milli-Q50, Millipore, Molsheim, France) was used throughout. 


\subsection{Preparation of Bimetallic PtAu Nanoparticles (PtAuBNps)}

The PtAuBNps were prepared by concomitant chemical reduction of $\mathrm{HAuCl}_{4} \cdot 3 \mathrm{H}_{2} \mathrm{O}$ and $\mathrm{H}_{2} \mathrm{PtCl}_{6} \cdot 6 \mathrm{H}_{2} \mathrm{O}$ with $\mathrm{NaBH}_{4}$ in the presence of a PVP stabiliser [19]. Briefly, an aqueous solution of PVP $(0.44 \mathrm{mM}, 50 \mathrm{~mL})$ was added to a $\mathrm{HAuCl}_{4} \cdot 4 \mathrm{H}_{2} \mathrm{O}(25 \mathrm{~mL}, 0.44 \mathrm{mM})$ solution under gentle, constant stirring at $0{ }^{\circ} \mathrm{C}$ for $15 \mathrm{~min}$. Thereafter, $25 \mathrm{~mL}$ of $\mathrm{H}_{2} \mathrm{PtCl}_{6} \cdot 6 \mathrm{H}_{2} \mathrm{O}(0.4 \mathrm{mM})$ was added with stirring for $30 \mathrm{~min}$ at $0{ }^{\circ} \mathrm{C}$. This was followed by a rapid injection of $\mathrm{NaBH}_{4}\left(6.67 \mathrm{~mL}, 16.5 \mathrm{mM}, 0{ }^{\circ} \mathrm{C}\right)$ under vigorous stirring, until a dark brown colloidal suspension of PtAuBNps were formed. The final concentration of the synthesised BNps was $0.18 \mathrm{mg} / \mathrm{mL}$.

\subsection{Preparation of Nanocomposites}

The method used was modified from previous reports [19-21]. The anticancer drug 5-FU was encased within a Tween 80 stabilised CS based nanocomposite. Briefly, $0.75 \mathrm{mg} / \mathrm{mL}$ CS solution (in $2 \%$ glacial acetic acid) was added to $3.8 \mathrm{mM}$ of 5 -FU solution (in $18 \mathrm{Mohm}$ water) in a 1:1 ratio $(v / v)$ with constant mixing. Thereafter, Tween $80(0.5 \% v / v)$ was added as a surfactant, and the $\mathrm{pH}$ adjusted to 4.8 with $0.1 \mathrm{M} \mathrm{NaOH}$. The prepared drug-polymer solution was mixed with $1.4 \mathrm{mM}$ TPP solution to obtain a CS: TPP ratio of $(2: 1 \mathrm{v} / \mathrm{v})$. The nanoparticle suspension was gently stirred for $30 \mathrm{~min}$ to allow adsorption of 5-FU onto the CSNps (CTF). Finally, $0.18 \mathrm{mg} / \mathrm{mL}$ of colloidal PtAuBNps was added dropwise to the CTF nanoparticles at a ratio of $(1: 1 v / v)$ under gentle, constant stirring for $180 \mathrm{~min}$, forming the nanocomposite, PtAu-CS-TPP-5FU/Tween 80 (PACTF). Finally, all drug loaded nanocomposites were purified by centrifugation at $15,000 \mathrm{rpm}$ at $4{ }^{\circ} \mathrm{C}$ for $15 \mathrm{~min}$ (Beckman Ultracentrifuge, Brea, CA, USA) and the pellet re-dispersed in $18 \mathrm{Mohm}$ water.

\subsection{Imaging, Nanoparticle Sizing and Zeta Potential Analysis}

The surface morphology, uniformity and size distribution of all nanoparticles (Nps) and nanocomposites were investigated using TEM (JEOL JEM 1010, Tokyo, Japan, functioning at $100 \mathrm{kV}$ ). Aqueous solutions of Nps/nanocomposites were deposited onto separate formvar coated 40-mesh copper grids (Ted Pella Inc., Redding, CA, USA), and air dried. Images were recorded using the iTEM Soft Imaging Systems (SIS) Megaview III (JEOL JEM 1010, Tokyo, Japan) fitted with a side-mounted 3-megapixel digital camera.

The particle size distribution, concentration and colloidal stability were measured by nanoparticle tracking analysis (NTA, Nanosight NS500; Malvern Instruments, Malvern, Worcestershire, UK). All PtAuBNp formulations were diluted 1:1000 in $18 \mathrm{Mohm}$ water and run in triplicates. Individual particles undergoing Brownian motion were captured and visualised through light scattering upon laser illumination. The NTA software measures the theoretical hydrodynamic diameter of particles by application of the Stokes-Einstein equation and the zeta ( $\zeta$ ) potential by Laser-Doppler microelectrophoresis through Smoluchowski modelling. All measurements were performed at $25^{\circ} \mathrm{C}$ and $24 \mathrm{~V}$.

\subsection{UV-Vis Spectrophotometry}

The confirmation of the PtAu core-shell formation, successful chitosan polymerisation and 5-FU entrapment was based on the optical changes of specific samples and verified against that in literature. Briefly, solutions of approximately $10 \mu \mathrm{L}$ were analysed over a wavelength range of 200-800 nm using a UV-vis spectrophotometer (JASCO V-730, JASCO Corporation, Hachioji, Japan).

\subsection{Fourier Transform Infra-Red (FTIR) Spectroscopy}

To identify surface-bound functional groups, and the chemical interactions between the carrier and the drug, FTIR analysis were conducted in a Perkin Elmer spectrum 100 FTIR spectrometer equipped with a diamond universal ATR sampling accessory. The spectra were acquired at a programmed range 
of $400-4000 \mathrm{~cm}^{-1}$ at a $1 \mathrm{~cm}^{-1}$ resolution. The spectra requisition was carried out using the Spectrum 10 analysis software (Perkin Elmer, Waltham, MA, USA).

\subsection{Drug Binding Studies}

The drug entrapment efficiency (EE) and loading content (LC) were estimated by the amount of drug liberated after centrifugation. Briefly, drug laden nanocomposites were centrifuged at 21,000 rpm for $15 \mathrm{~min}$ at $10^{\circ} \mathrm{C}$ (Beckman Ultracentrifuge, Brea, CA, USA), to separate the bound and unbound drug. The analysis of unbound or free 5-FU in the supernatant was determined by UV-vis spectroscopy at a wavelength $481 \mathrm{~nm}$. Measurements were conducted in triplicate. The theoretical drug content (TDC), encapsulation efficiency (EE), actual drug content and loading capacity (LC) were calculated using Equations (1)-(4) [17].

$$
\begin{gathered}
\text { TDC }=\frac{\text { Weight of } 5-\text { FU }}{\text { Weight of nanocomposite }} \\
\text { EE }(\%)=\frac{\text { Total } 5-\text { FU added }- \text { Free } 5-\text { FU }}{\text { Total } 5-\text { FU added }} \times 100 \\
\text { ADC }(\mu \mathrm{g})=\text { TDC } \times \text { EE }(\%) \\
\text { LC }(\%)=\frac{\text { Total } 5-\text { FU added }- \text { Free } 5-\text { FU }}{\text { weight of nanocomposite }} \times 100
\end{gathered}
$$

\subsection{In Vitro Mucoadhesive Response}

The bioadhesive propensity of the nanocomposites was studied in vitro as a means of the rheological synergism that occurs at the functional group level between nanoparticles/nanocomposites and a porcine mucin model. Approximately, $1 \mathrm{~mL}$ of porcine mucin (PM, $400 \mu \mathrm{g} / \mathrm{mL})$ suspension in simulated intestinal fluid $(25 \% \mathrm{v} / \mathrm{v}, \mathrm{pH} 6.8)$ was mixed with $1 \mathrm{~mL}$ of the respective nanocomposite suspensions $(20 \mu \mathrm{g} / \mathrm{mL})$, and gently shaken $(50 \mathrm{rpm})$ at $37^{\circ} \mathrm{C}$ for $6 \mathrm{~h}$. Thereafter, free PM was separated by centrifugation at 21,000 rpm for $30 \mathrm{~min}$ at $10{ }^{\circ} \mathrm{C}$ (Eppendorf $5424 \mathrm{R}$, Hamburg, Germay). The degree of interaction between the nanocomposites and mucin was determined by measuring the absorbance of the remaining free PM in the supernatant in a spectrophotometer set at wavelength of $251 \mathrm{~nm}$, with intestinal fluid as the blank. The percentage mucoadhesion was calculated using Equation (5).

$$
\text { Mucoadhesion }(\%)=\frac{\text { Total Mucin before }- \text { Free Mucin after }}{\text { Total Mucin before }} \times 100
$$

\subsection{Pharmacokinetic Studies}

The ability of the prepared nanocomposites to release the loaded drug in response to specific biological environments was investigated. Approximately, $5 \mathrm{~mL}$ of drug loaded nanocomposites $(50 \mu \mathrm{g} / \mathrm{mL})$ were placed in dialysis bags (MWCO $2000 \mathrm{Da})$, hermetically sealed and immersed separately in $10 \mathrm{~mL}$ of PBS (pH 7.4, 6.5, 5.0 and 4.5), with gentle stirring at $37^{\circ} \mathrm{C}$. Periodically, $10 \mu \mathrm{L}$ aliquots were withdrawn and analysed. The amount of 5-FU released was determined using UV-vis spectroscopy at $266 \mathrm{~nm}$. The cumulative drug release (\%) was calculated relative to the total absorbance of 5-FU loaded onto the nanocomposites using Equation (6).

$$
\text { Cumulative }(\%)=\frac{\text { Abs of free } 5-\text { FU }}{\text { Abs of total } 5-\text { FU loaded }} \times 100
$$

The drug release data were modelled using the zero-order, first-order, Higuchi's square root of time equation and the Korsmeyer-Peppas power law kinetic equations [22-24] (Table 1). 
Table 1. Time-dependent pharmacokinetic modelling of dissolution data to ascertain drug release mechanisms at acidic and physiological $\mathrm{pH}$ conditions.

\begin{tabular}{cc}
\hline Kinetic Model & Equation \\
\hline Zero-order & $R_{\mathrm{t}}=R_{0}+K_{0} t$ \\
First-order & $\operatorname{Ln} R_{\mathrm{t}}=\ln R_{0}+K_{1} t$ \\
Higuchi & $R_{\mathrm{t}}=K_{\mathrm{H}} t^{1 / 2}$ \\
Korsmeyer-Peppas & $R_{\mathrm{t} /} R_{\infty}=K_{\mathrm{k}} t^{n}$ \\
\hline
\end{tabular}

$K_{0}, K_{1}, K_{\mathrm{H}}$, and $K_{\mathrm{k}}$ are release rate constants; $n$ is the release exponent (indicative of drug release mechanism); $R_{0}$ is the initial amount of 5-FU in the nanocomposite; $R_{\infty}$ is the total amount of drug dissolved when the dosage form is exhausted; and $R_{\mathrm{t}}$ is the amount of 5-FU released at time $t$.

\subsection{In Vitro Cytotoxicity Assessment}

All cells were cultured in EMEM supplemented with 10\% FBS and 1\% antibiotics. The cells were maintained in $25 \mathrm{~cm}^{2}$ culture flasks under standard culture conditions $\left(37{ }^{\circ} \mathrm{C}, 5 \% \mathrm{CO}_{2}\right.$ and $95 \%$ relative humidity), and were sub-cultured routinely. All biological assays were conducted under aseptic conditions in an Airvolution Class II biosafety laminar flow hood (United Scientific, Western Cape, South Africa).

The antitumour activities of PtAuBNps and their nanocomposites were evaluated in vitro using the MTT and SRB assays in three human cancer cell lines (Caco-2, HepG2 and MCF-7) and a non-cancer cell line (HEK293). Exponentially growing cells were trypsinised, seeded in a 96-well plate at a cell density of $2.5 \times 10^{3}$ cells/well and incubated overnight at $37^{\circ} \mathrm{C}$. Thereafter, spent medium was replenished with $100 \mu \mathrm{L}$ fresh growth medium, to which the respective compounds were added at various concentrations $(5,15,35$ and $50 \mu \mathrm{g} / \mathrm{mL})$, and incubated for $48 \mathrm{~h}$ at $37^{\circ} \mathrm{C}$. Wells containing cells only served as the positive control. All assays were done in triplicate. The MTT and SRB assays were conducted as described below, after the 48-h incubation period. The cell viability (\%) in each of the assays was calculated using Equation (7).

$$
\text { Cell viability }(\%)=\frac{\text { Abs of treated cells }}{\text { Abs of untreated cells }} \times 100
$$

For the MTT assay, the culture medium was aspirated and replenished with $100 \mu \mathrm{L}$ of EMEM containing $10 \%$ MTT reagent $\left(5 \mathrm{mg} / \mathrm{mL}\right.$ in PBS), and incubated for $4 \mathrm{~h}$ at $37^{\circ} \mathrm{C}$. Thereafter, the MTT-medium solution was carefully removed, and $100 \mu \mathrm{L}$ DMSO added to each well to ensure cell permeation and solubilisation of the formazan sediment. Absorbance was read using a Mindray MR-96A microplate reader (Vacutec, Hamburg, Germany) at $570 \mathrm{~nm}$, with DMSO as a blank.

For the SRB assay, the cell monolayers were fixed by gently layering $25 \mu \mathrm{L}$ cold TCA $(50 \% w / v)$ onto the growth medium. The cells were incubated for $1 \mathrm{~h}$ at $4{ }^{\circ} \mathrm{C}$, washed $(3 \times)$ with distilled water and air dried. The TCA-fixed cells were then stained with $50 \mu \mathrm{L}$ of SRB $(0.4 \% w / v$ in $1 \%$ glacial acetic acid) dye for $30 \mathrm{~min}$ at $37^{\circ} \mathrm{C}$, washed $(3 \times)$ with $1 \%$ acetic acid to remove the non-ligated dye, and the plates air dried. Finally, the protein-bound dye was extracted with $100 \mu \mathrm{L}$ of Tris buffer $(10 \mathrm{mM}$, $\mathrm{pH}$ 10.5), and absorbances measured at $565 \mathrm{~nm}$ using Tris base as the blank.

\subsection{Apoptosis Assay}

The acridine orange/ethidium bromide $(\mathrm{AO} / \mathrm{EB})$ dual staining method is a convenient, rapid and economical method for the quantitative and qualitative analysis of possible apoptosis induction by the drug laden PtAuBNps. Cells were seeded at a cell density of $1.5 \times 10^{5}$ in a 24 -well plate and incubated at $37^{\circ} \mathrm{C}$ in $5 \% \mathrm{CO}_{2}$ for $24 \mathrm{~h}$, to allow the cells to attach. Thereafter, the culture medium was aspirated, replenished with $0.5 \mathrm{~mL}$ of complete medium, and cells were treated with nanocomposites at predetermined $\mathrm{IC}_{50}$ values (average of the two assays). A nanoparticle/nanocomposite free positive control was included. After a $24 \mathrm{~h}$ incubation at $37^{\circ} \mathrm{C}$, the spent medium was removed, and cells washed $(2 \times)$ with $100 \mu \mathrm{L}$ of cold PBS. Cells were stained with $12 \mu \mathrm{L}$ of the dye solution $(1: 1 v / v$ AO: 
$\mathrm{EB}, 100 \mathrm{mg} / \mathrm{mL}$ in PBS) for $5 \mathrm{~min}$. Cells were viewed under an Olympus fluorescent microscope (200× magnification), fitted with a CC12 fluorescent camera (Olympus Co., Tokyo, Japan). The number of viable cells and apoptotic bodies were tallied using the Soft Imaging System (SIS) software (Olympus Co., Tokyo, Japan). The apoptotic indices were calculated according to Equation (8).

$$
\text { Apoptotic Index }=\frac{\text { Number of Apoptotic cells }}{\text { Total number of cells counted }}
$$

\subsection{Statistical Analysis}

The results in triplicate are reported as mean $\pm \mathrm{SD}$ (standard deviation). All statistical analyses were performed using GraphPad Prism version 5.01 (GraphPad Software Inc., La Jolla, CA, USA). The significance of results and differences between the control and test were determined using a one-way analysis of variance (ANOVA). The Dunnett's post hoc test was used for the growth inhibition assays. Statistical significance between groups was considered significant at ${ }^{* *} p<0.01$ and ${ }^{*} p<0.05$. Dissolution kinetics parameters were evaluated using Microsoft Excel $2016^{\mathrm{TM}}$ and DD Solver software. The parameters are indicated in Table 1 . The best-fit dissolution profile was identified at $\mathrm{r}^{2}$ values $\geq 0.99$.

\section{Results}

\subsection{Nanoparticle Morphology, Sizing and Zeta Potential}

TEM reflected the ultrastructural morphology, distribution and uniformity of all nano-formulations (Figure 2A-D). The PtAuBNps (Figure 2A) displayed a near spherical morphology and were well dispersed due to passivation with PVP, as observed in the literature [19-21]. All CS based nano-formulations (Figure 2B-D) were predominantly monodispersed, uniform spherical nanostructures with smooth surfaces. An increase in size for the drug bearing nanocomposites CTF (Figure 2C), and PACTF (Figure 2D) was evident, with the latter appearing denser and more compact.

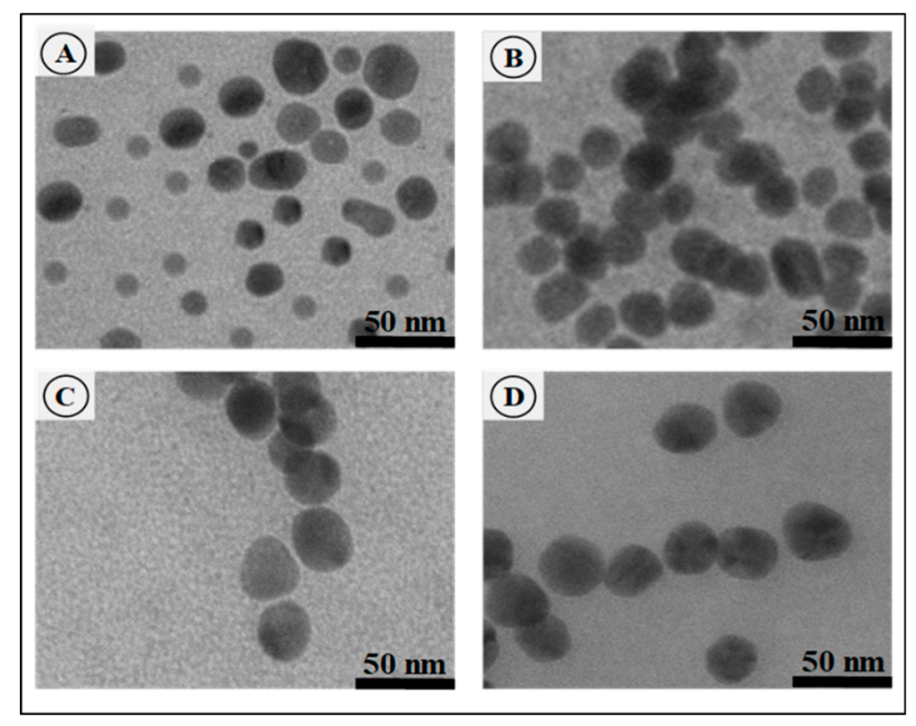

Figure 2. TEM micrographs of: (A) PtAuBNps; (B) PtAuCSBNps; (C) CTF; and (D) PACTF. Bar $=50 \mathrm{~nm}$. CTF, CS-TPP-5-FU/Tween 80; PACTF, PtAu-CS-TPP-5-FU/Tween 80.

NTA analysis (Table 2) strongly correlated with the TEM results, and revealed PtAuBNps to have a hydrodynamic size of $69.9 \pm 3.2 \mathrm{~nm}$ and a zeta $(\zeta)$ potential of $-21.5 \mathrm{mV}$. Conjugation of CS to PtAuBNps increased the average hydrodynamic size to $88.4 \pm 10.8 \mathrm{~nm}$, with a shift from a negative to a highly positive $\zeta$ potential value $(58.2 \pm 1.1 \mathrm{mV})$. 
Table 2. Size distribution and zeta potential of BNps and nanocomposites. Data are represented as mean $\pm \mathrm{SD}(n=3)$.

\begin{tabular}{ccc}
\hline Sample & Particle Size $(\mathbf{n m})$ & $\zeta$ Potential $(\mathbf{m V})$ \\
\hline PtAuBNps & $69.9 \pm 3.2$ & $-21.5 \pm 1.4$ \\
PtAuCSBNps & $88.4 \pm 10.8$ & $58.2 \pm 1.1$ \\
PACTF & $108.6 \pm 8.2$ & $30.5 \pm 0.6$ \\
CTF & $118.8 \pm 8.6$ & $28.3 \pm 2.6$ \\
\hline
\end{tabular}

CTF, CS-TPP-5-FU/Tween 80; PACTF, PtAu-CS-TPP-5-FU/Tween 80.

\subsection{UV-Vis and FTIR Spectroscopy}

The SPR of the PtAuBNPs (Figure 3A) presented as a single narrow peak centred at $224 \mathrm{~nm}$, correlating with the literature and confirming the successful synthesis of core-shell nanostructures [25]. Chitosan functionalised PtAuBNps (Figure 3B) exhibited a single broad red shift with an SPR resonant extinction peak at $235 \mathrm{~nm}$, indicating a change in the local refractive index due to successful polymer conjugation and an increase in particle size. Successful encapsulation and loading of 5-FU were confirmed in the nanocomposites PACTF and CTF (Figure 3C,D). The characteristic absorbance peak of 5-FU at $266 \mathrm{~nm}$ (Figure 3E) displayed a blue shift to $261 \mathrm{~nm}$ and $263 \mathrm{~nm}$ for PACTF and CTF, respectively, correlating to the literature [16].

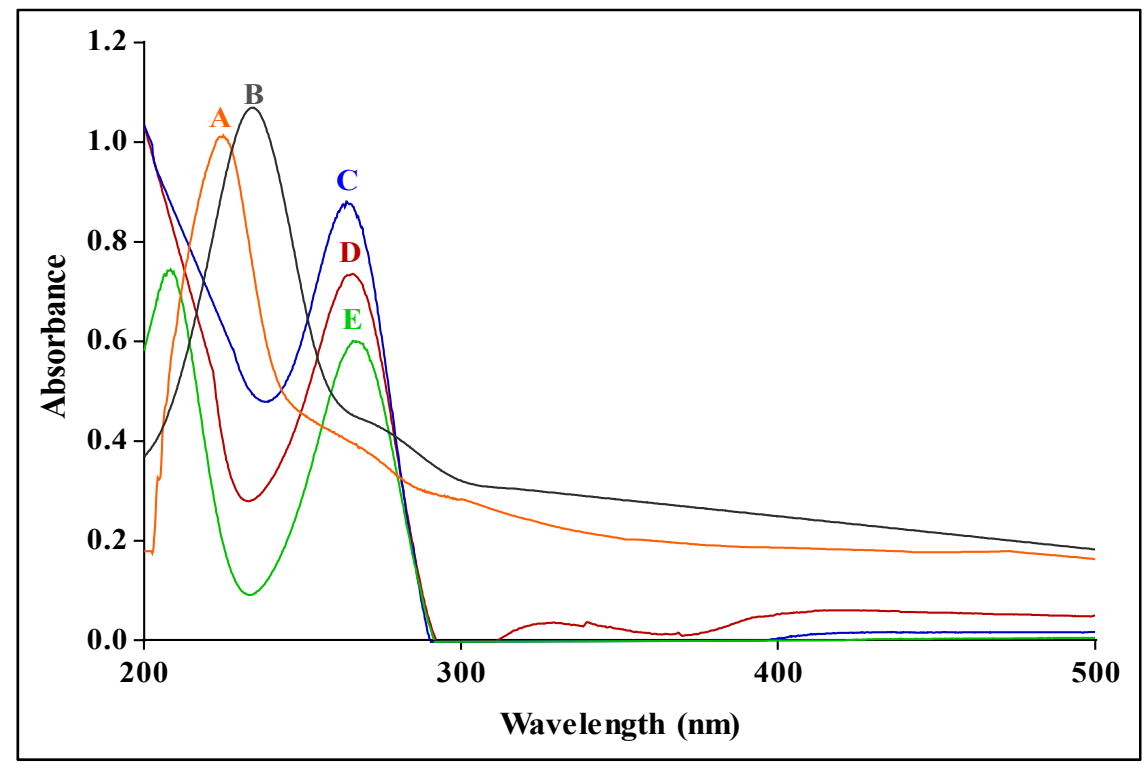

Figure 3. UV-vis spectra of: (A) PtAuBNps; (B) PtAuCSBNps; (C) PACTF; (D) CTF; and (E) 5-FU. 5-FU, 5-Fluorouracil; CTF, CS-TPP-5-FU/Tween 80; PACTF, PtAu-CS-TPP-5-FU/Tween 80.

The FTIR spectrum of 5-FU (Figure 4A) displayed the characteristic vibrational bands within $3000-2825 \mathrm{~cm}^{-1}$, attributed to C-H stretching. Absorption bands at $\sim 1726 \mathrm{~cm}^{-1}$ and $1669 \mathrm{~cm}^{-1}$ are ascribed to $\mathrm{C}=\mathrm{O}$ and $\mathrm{N}-\mathrm{H}$ vibrations, respectively. Bands at $\sim 1428-1504 \mathrm{~cm}^{-1}$ are due to $\mathrm{C}=\mathrm{C}$ and $\mathrm{C}=\mathrm{N}$ stretching. The band at $\sim 1242 \mathrm{~cm}^{-1}$ is due to $\mathrm{C}-\mathrm{N}$ vibrations $[2,26]$. The $\mathrm{CS}$ spectra (Figure 4B) exhibited characteristic O-H and N-H stretching bands at $\sim 3352 \mathrm{~cm}^{-1}$, stretching vibrations of the C-H bond at $\sim 2935 \mathrm{~cm}^{-1}, \mathrm{C}=\mathrm{O}$ stretching of the amide I band at $\sim 1647 \mathrm{~cm}^{-1}$, vibrations of the N-H group of the amide II band at $\sim 1573 \mathrm{~cm}^{-1}$, anti-symmetric stretching of the $(\mathrm{C}-\mathrm{O}-\mathrm{C})$ bridge at $\sim 1150 \mathrm{~cm}^{-1}$, and a $\mathrm{NH}_{2}$ peak at $\sim 895 \mathrm{~cm}^{-1}$, all corresponding to that reported in the literature $[27,28]$. Drug loaded nanocomposites (Figure $4 \mathrm{C}, \mathrm{D}$ ) displayed most of the signature stretching and deformation vibrations of CS and 5-FU with minor shifts. However, the 5-FU footprints were slightly masked and diminished by the nanoparticle spectra, suggesting successful 5-FU encapsulation. 


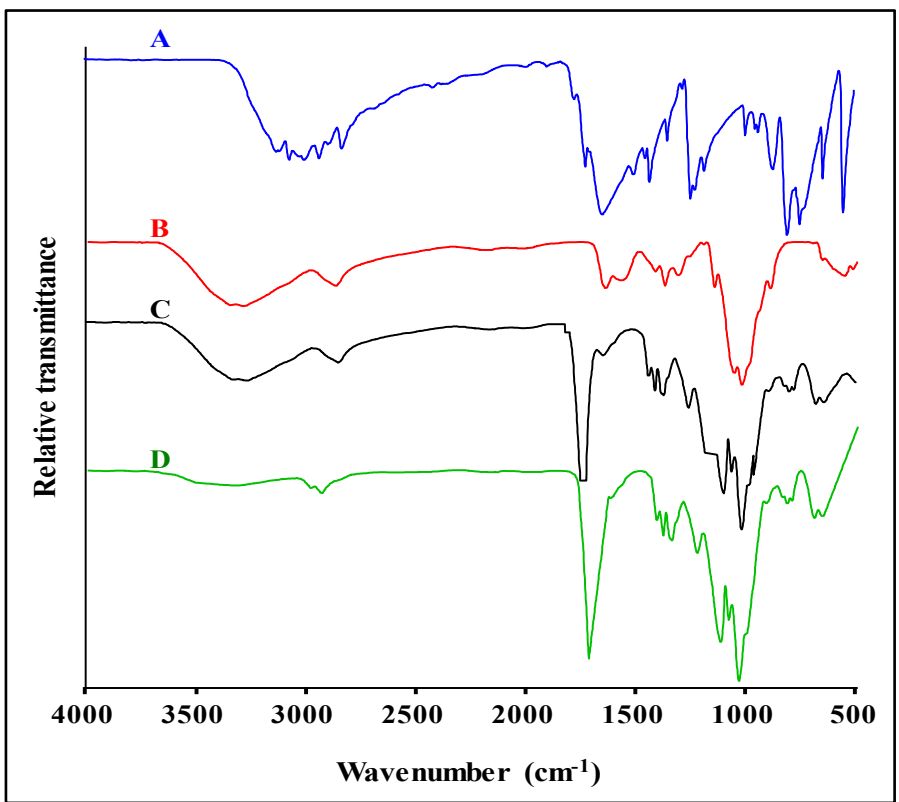

Figure 4. FTIR Spectra of: (A) 5-FU; (B) CS; (C) PACTF; and (D) CTF. CTF, CS-TPP-5-FU/Tween 80; PACTF, PtAu-CS-TPP-5-FU/Tween 80.

\subsection{Drug Binding Studies}

The encapsulation efficiency (EE) and loading content (LC) of 5-FU was $90.17 \%$ and $22.56 \%$ in PACTF, with a lower EE of $87.24 \%$ and a higher LC of $23.24 \%$ in CTF (Table 3).

Table 3. Drug loading efficiency, theoretical drug content, actual drug content and drug loading content of nanocomposites.

\begin{tabular}{ccccc}
\hline Sample & TDC $(\mu \mathrm{g})$ & EE $(\%)$ & ADC $(\mu \mathrm{g})$ & LC $(\%)$ \\
\hline CTF & 139.21 & 87.24 & 121.45 & 23.24 \\
PACTF & 96.34 & 90.17 & 88.80 & 22.56 \\
\hline
\end{tabular}

ADC, Actual drug content; CTF, CS-TPP-5-FU/Tween 80; EE, Encapsulation efficiency; LC, Drug loading content: PACTF, PtAu-CS-TPP-5-FU/ Tween 80; TDC, Theoretical drug content.

\subsection{In Vitro Mucoadhesive Response}

CS functionalised PtAuBNps exhibited the highest porcine mucin (PM) binding efficiency $(86.24 \pm 3.82 \%)$ (Table 4), while the free drug and PtAuBNps, showed lower mucoadhesive ability, possibly due to charge repulsions. Nanocomplexes, PACTF $(68.74 \pm 2.87 \%)$ and CTF $(67.05 \pm 4.21 \%)$, demonstrated a slightly lower degree of mucoadhesion than the PtAuCSBNps, possibly due to the utilisation of the free surface amino groups through TPP cross-linking, resulting in weaker binding interactions.

Table 4. Binding efficiencies of nanoparticles/nanocomposites to porcine mucin.

\begin{tabular}{cc}
\hline Compound & Mucoadhesion (\%) \\
\hline PtAuBNps & $8.72 \pm 1.67$ \\
PtAuCSBNps & $86.24 \pm 3.82$ \\
PACTF & $68.74 \pm 2.87$ \\
CTF & $60.05 \pm 4.21$ \\
5-FU & $21.51 \pm 3.28$
\end{tabular}

Data are represented as mean $\pm \mathrm{SD}(n=3)$. 5-FU, 5-Fluorouracil, CTF, CS-TPP-5-FU/Tween 80; PACT, PtAu-CS-TPP-5-FU/Tween 80. 


\subsection{In Vitro Pharmacokinetics Studies}

The pharmacokinetic profiles PACTF and CTF (Figure 5 and Tables S1 and S2), show that the release of 5-FU was slow at neutral conditions for CTF $(35.11 \% \pm 1.17$ in $24 \mathrm{~h})$ and PACTF $(30.80 \pm 1.75$ in $24 \mathrm{~h}$ ), but accelerated at lower $\mathrm{pH}$. A rapid release was observed at $\mathrm{pH} 4.5$ with up to $70 \%$ of 5 -FU eluted over the $24 \mathrm{~h}$ period. Approximately, $54.0 \pm 1.8 \%, 65.2 \pm 0.66 \%$ and $74.1 \pm 0.88 \%$ were eluted from PACTF at $\mathrm{pH}$ 6.5, 5.0 and 4.5, respectively. At neutral milieu, the release from both nanocomposites closely followed the zero-order kinetic model with limited dissolution of 5-FU by non-Fickian diffusion, while release under acidic conditions followed the zero-order model $\left(r^{2}=0.977\right)$. However, the liberation of 5-FU from CTF and PACTF occurred through anomalous diffusion.

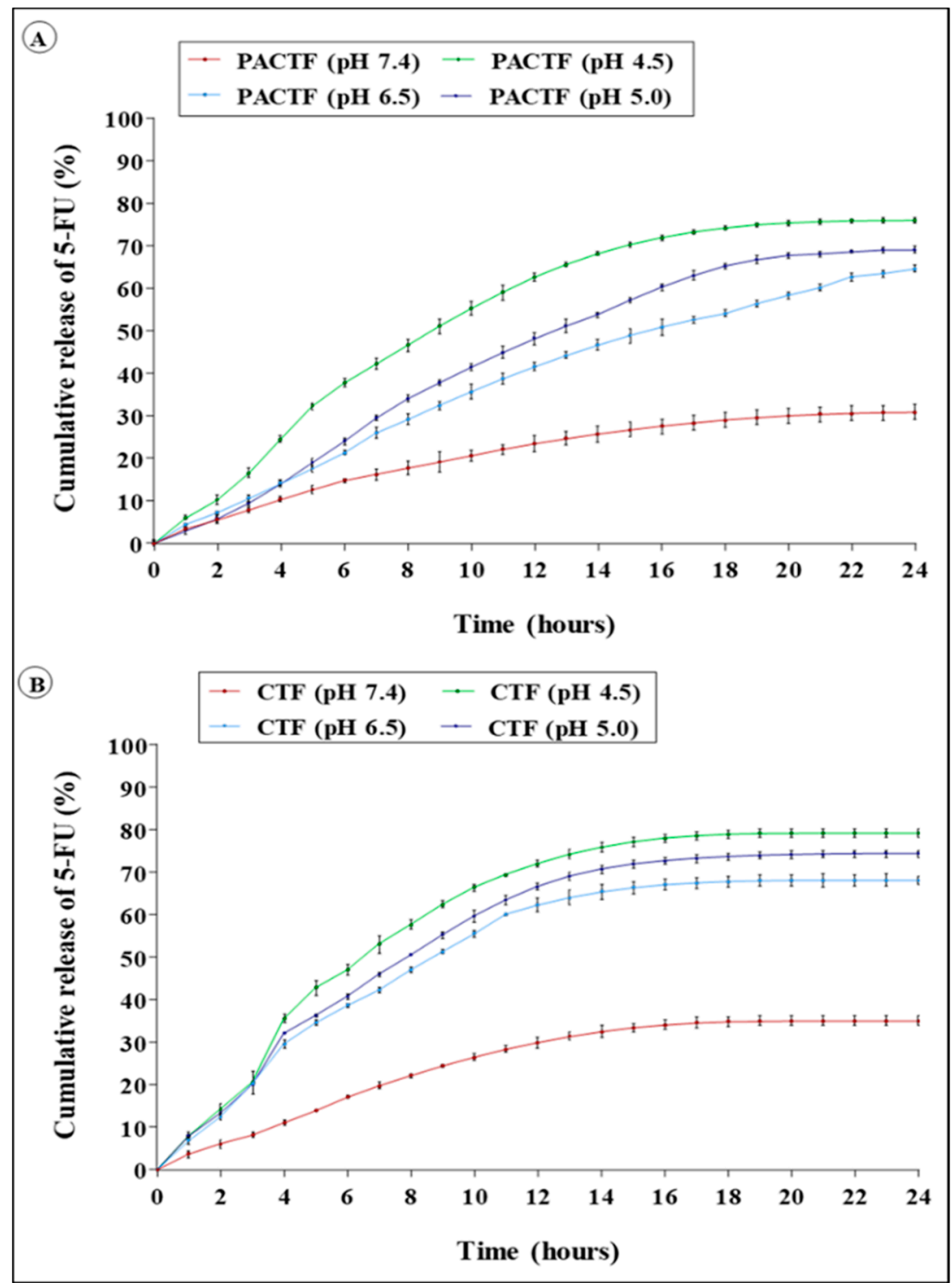

Figure 5. In vitro cumulative drug release profile of 5-fluorouracil encapsulated nanocomposites at $\mathrm{pH}$ 4.5, 5.0, 6.5 and 7.4: (A) PACTF; and (B) CTF.

\subsection{In Vitro Cytotoxicity}

The cytotoxicity profiles and $\mathrm{IC}_{50}$ values of PtAuBNPs, PtAuCSBNPs, CTF and PACTF (Figures 6 and 7 and Table 5), showed that the PtAuBNps exerted low cytotoxicity at the highest tested concentration, with up to $75 \%$ maximum cell viability in all cell lines in both assays. 


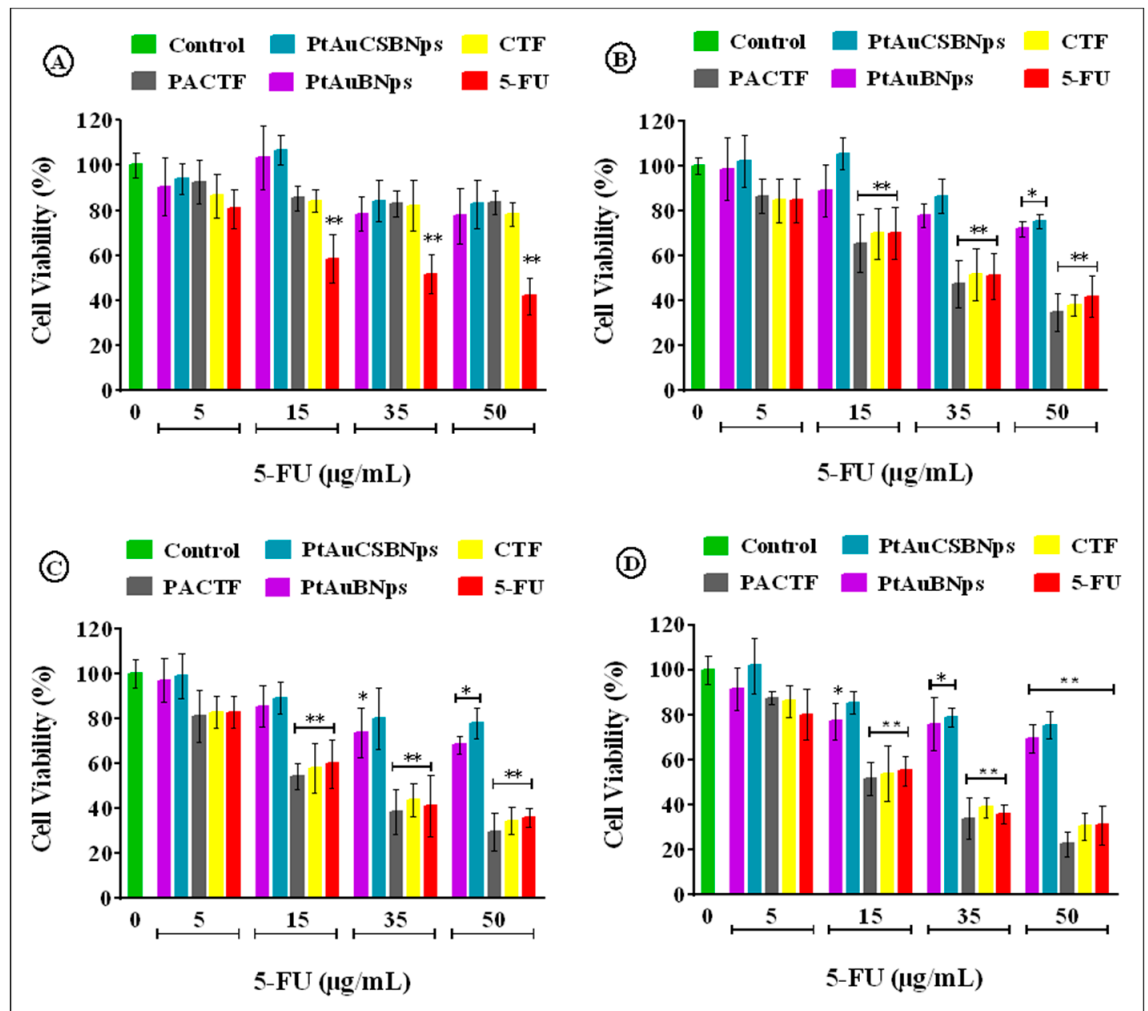

Figure 6. MTT cytotoxicity assay of bimetallic nanoparticles and drug bearing nanocomposites in: (A) HEK293; (B) MCF-7; (C) HepG2; and (D) Caco-2 cell lines. Data are presented as mean \pm SD $(n=3)$. ${ }^{*} p<0.05,{ }^{* *} p<0.01$ were considered statistically significant.

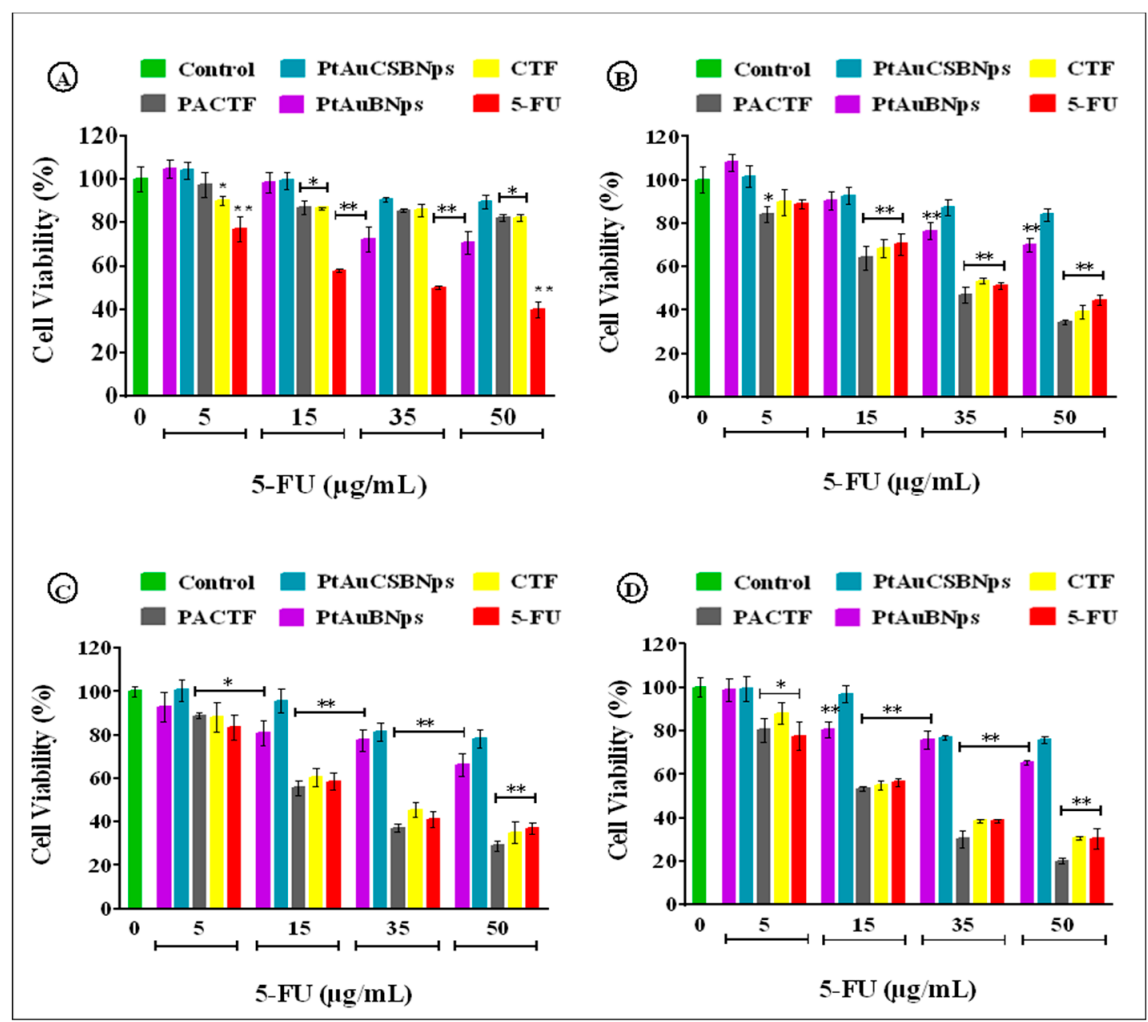

Figure 7. SRB cytotoxicity assay of bimetallic nanoparticles and drug bearing nanocomposites in (A) HEK293; (B) MCF-7; (C) HepG2; and (D) Caco-2 cell lines. Data are presented as mean \pm SD $(n=3)$. ${ }^{*} p<0.05,{ }^{* *} p<0.01$ were considered statistically significant. 
Table 5. $\mathrm{IC}_{50}$ values of free $5 \mathrm{U}$ and 5-FU loaded nanocomposites in HEK293, HepG2, Caco-2 and MCF-7 cell lines for the MTT and SRB assays.

\begin{tabular}{ccccccc}
\hline \multirow{2}{*}{ Cell Lines } & \multicolumn{3}{c}{ IC $_{\mathbf{5 0}}(\mu \mathrm{g} / \mathrm{mL})$-MTT Assay } & \multicolumn{3}{c}{ IC $_{\mathbf{5 0}}(\boldsymbol{\mu g} / \mathrm{mL})$-SRB Assay } \\
\cline { 2 - 7 } & PACTF & CTF & 5-FU & PACTF & CTF & 5-FU \\
\hline HEK293 & - & - & 31.79 & - & - & 30.84 \\
MCF-7 & 29.73 & 33.57 & 36.06 & 30.12 & 34.99 & 38.67 \\
HepG2 & 22.85 & 25.21 & 25.27 & 23.10 & 26.24 & 25.38 \\
Caco-2 & 18.98 & 21.99 & 20.41 & 19.25 & 22.58 & 21.19 \\
\hline \multicolumn{4}{c}{ “- indicates IC } \\
50 could not be estimated accurately.
\end{tabular}

\subsection{Apoptosis Induction Studies}

The fluorescent images of the control and treated cells are depicted in Figure 8, and the apoptotic index (AI) in Table 6. All control cells emitted green fluorescence indicative of healthy cells with an intact cell membrane. Conversely, all cells treated with 5-FU, PACTF and CTF at their $\mathrm{IC}_{50}$ values, formed apoptotic bodies of varying degrees in all cell lines. 5-FU induced high degrees of cell death in all cell lines through both apoptotic and necrotic pathways. The encapsulation of 5-FU brought about biocompatibility and controlled cell death as displayed by the very low apoptotic indices of the nanocomposites in the HEK293 (<0.052) cells, and the considerably higher indices in the three cancer cell lines (>0.360). The MCF-7 cell line showed cells mainly in early apoptosis, while the Caco- 2 and HepG2 cells were more sensitive with higher apoptotic indices and characteristic apoptotic features (membrane blebs, chromatin condensation and fragmentation).

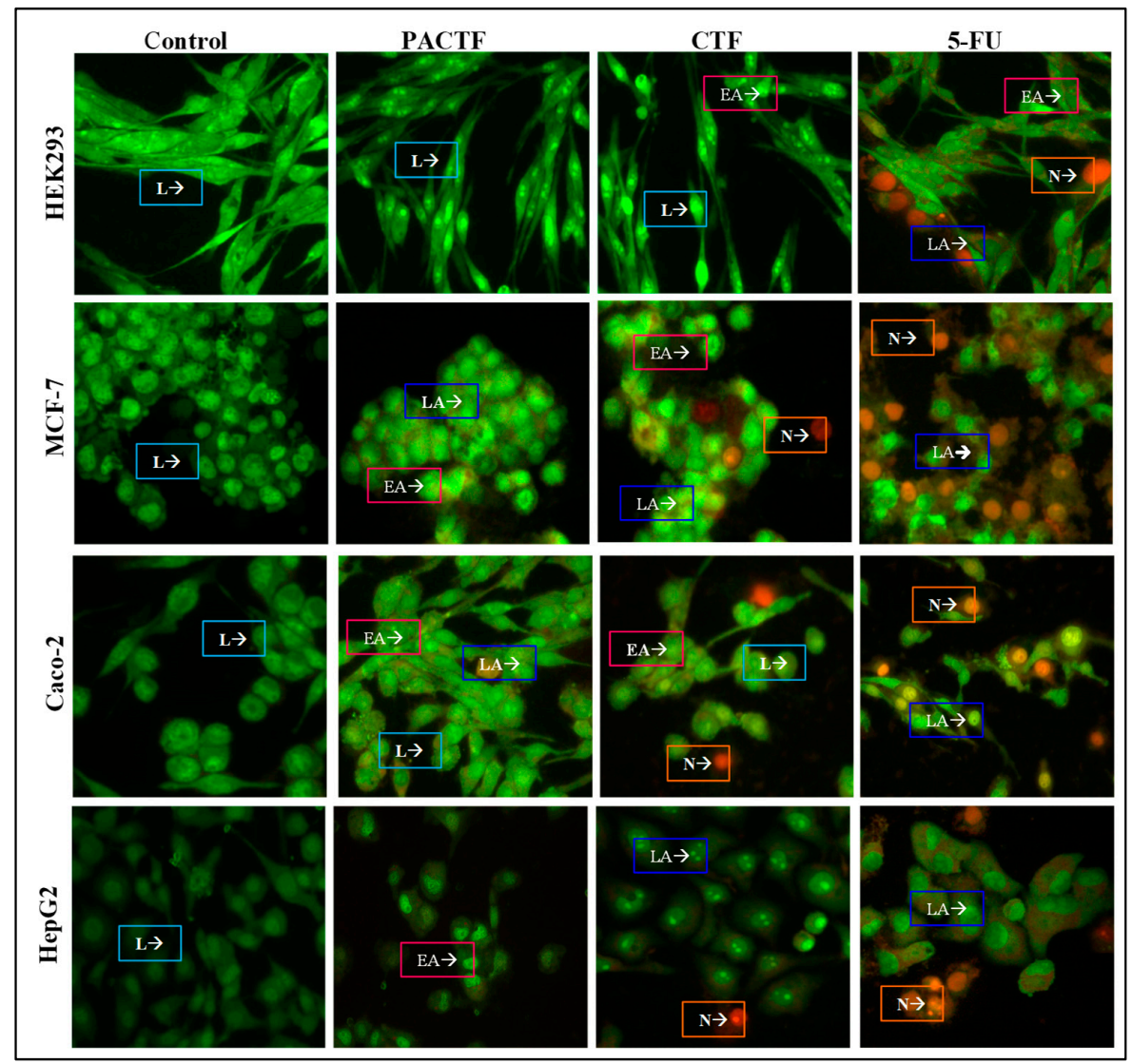

Figure 8. Fluorescence images of dual acridine orange/ethidium bromide stained cells showing induced morphological changes in HEK293, MCF-7, Caco-2 and HepG2 cell lines at 20× magnification. L, Live cells; EA, Early apoptotic cells; LA, Late apoptotic cells N, Necrotic cells. 
Table 6. Apoptotic indices of free 5-FU and 5-FU loaded nanocomposites.

\begin{tabular}{cccc}
\hline \multirow{2}{*}{ Cell Lines } & \multicolumn{3}{c}{ Apoptosis Index } \\
\cline { 2 - 4 } & PACTF & CTF & 5-FU \\
\hline HEK293 & 0.034 & 0.052 & 0.389 \\
MCF-7 & 0.345 & 0.321 & 0.361 \\
HepG2 & 0.542 & 0.512 & 0.549 \\
Caco-2 & 0.621 & 0.549 & 0.624 \\
\hline
\end{tabular}

5-FU, 5-Fluorouracil; CTF, CS-TPP-5-FU/Tween 80; PACTF, PtAu-CS-TPP-5-FU/Tween 80.

\section{Discussion}

The morphological features and colouration of the CSNps under TEM were similar to previously reported findings $[17,29,30]$. Characteristically, metallic nanoparticles with high atomic numbers possess excellent light scattering power and appear dark in colouration [31]. Nanocomposite PACTF appeared to have areas of dark pigmentation, suggesting the presence of small-sized PtAuBNps within dense chitosan cross-linked nanospheres.

Zeta $(\zeta)$ potential is the magnitude of the electrostatic potential generated on the edge of the slipping plane between the particle and the dispersant medium. In general, particles displaying a $\zeta$ potential value $>30 \mathrm{mV}$ or $<-30 \mathrm{mV}$, will have a strong degree of electrostatic repulsion between adjacent similarly charged particles, leading to better colloidal dispersion [32]. However, a $\zeta$ potential $<15 \mathrm{mV}$ or $>-15 \mathrm{mV}$, will have attractive forces that exceed repulsive forces, causing particles to aggregate. Conjugation of CS to PtAuBNps increased the average hydrodynamic size to $88.4 \pm 10.8 \mathrm{~nm}$, with a shift from a negative to a highly positive $\zeta$ potential value $(58.2 \pm 1.1 \mathrm{mV})$. This finding was in keeping with similar analysis conducted on CS functionalised AuNps [17,33-35]. The change in surface potential for PtAuCSBNps suggest strong electrostatic interactions between the protonated CS and the negatively charged surface of the PtAuBNps. Such high surface potential imparts a high degree of colloidal stability, to facilitate efficient cellular uptake by the negatively charged cellular membrane. The loading of 5-FU brought about an increase in size to $118.8 \pm 8.6 \mathrm{~nm}$ for CTF and $108.6 \pm 8.2 \mathrm{~nm}$ for PACTF. Furthermore, CTF $(28.3 \pm 2.6 \mathrm{mV})$ and PACTF $(30.5 \pm 0.6 \mathrm{mV})$ had lower $\zeta$ potentials than PtAuCSBNps, which can be ascribed to the consumption of free amine groups through TPP cross-linking and drug encapsulation, corroborating FTIR findings. The smaller hydrodynamic size of PACTF is possibly due to the addition of PtAuBNps, which condensed the CS framework. Previous studies on these bimetallic nanoparticles encapsulating the drug, doxorubicin, showed similar increases in size and zeta potential [17]. However, the sizes of these 5-FU nanocomplexes were slightly larger with marginally lower zeta potentials. Studies with functionalised gold nanoparticles showed a similar trend forming larger nanocomplexes but with high zeta potentials [35]. No studies using functionalised platinum nanoparticles for 5-FU delivery were found for comparison. Overall, these investigated nanocomplexes displayed physiochemical properties deemed to be critical for better tissue penetration, long-term storage and enhanced therapeutic effects.

Spherical AuNps dispersed in water display a strong SPR absorbance band in the visible region $(520 \mathrm{~nm})$, and PtNps in the near-infrared region $(220 \mathrm{~nm})$, which is attributed to in-plane dipole resonance [36]. The formation of Au core-Pt shell nanostructures is accompanied by a blue shift and quenching of AuNps' SPR, as Pt shell atoms epitaxially nucleate and grow on the surface of the Au core, until there is complete disappearance of the AuNps SPR [37]. The red shift following polymer conjugation has been previously reported $[35,38,39]$. FTIR is a well-established technique to identify and confirm the functional groups present by the magnitude, relative intensity and shape of the absorption bands that arise through stretching and deformation vibration. FTIR spectroscopy confirmed the chemical structure and functional groups present in CS, PtAuCSBNp, PACTF, CTF and 5-FU and corroborated that of UV-vis spectroscopy. 
The results of drug encapsulation suggest that there is a strong correlation between $\zeta$ potential analysis and EE, with a higher $\zeta$ potential in PACTF relating to a higher EE, while the compactness possibly resulted in the lower LC. These findings were consistent with similar 5-FU binding studies conducted with CS/Au nanocomposites [26]. Our previous studies, using doxorubicin containing PtAuCSBNps with slightly lower $\zeta$ potentials, produced lower drug encapsulation averaging around $70 \%$ [17], further confirming the correlation between $\zeta$ potential and EE. Furthermore, EE of 74\% and $79 \%$ of 5-FU was reported for CS functionalised and folate-CS functionalised gold nanoparticles which displayed higher $\zeta$ potentials $(>50 \mathrm{mV}$ ), which was still lower than that recorded for PACTF in this study. Although this encapsulation efficiency for the PtAuCSBNps was good, there is a need to improve its biostability for enhanced therapeutic effect especially for in vivo applications. The development of a bioadhesive drug delivery system has the potential to increase the residence time at the application site, increase drug permeation and bioavailability. Our findings support the notion that the positively charged amine groups of CS are mainly responsible for the carrier's bioadhesive propensity [40]. This phenomenon occurs specifically at the molecular level, through electrostatic interactions between the positively charged amino groups of CS and the negatively charged sulphonic acid resides in the mucin, bringing about rheological synergism [41-43]. Hence, this system has the potential to pass through the mucosal layer, enhancing its attractiveness as a drug delivery system.

Tumour tissue presents a mildly acidic microenvironment ( $\mathrm{pH}$ 6.5-5.0) due to vascular irregularities, hypoxia and high glycolytic metabolism, leading to the production and accumulation of acidic metabolites, with lower acidity occurring in intracellular organelles, viz., endosomes and lysosomes ( $\mathrm{pH}$ 5.5-4.0) [44,45]. Recently, pH-responsive release systems have emerged as attractive strategies to selectively target tumour acidity, enhance the therapeutic index and reduce side effects by providing spatiotemporal control over drug release in the body $[46,47]$. CTF displayed a characteristic biphasic release pattern at acidic environments, comprised of an initial release surge over the first $10 \mathrm{~h}$, followed by a slow gradual release of 5-FU in a plateau phase for the subsequent $14 \mathrm{~h}$. This release behaviour has previously been reported for polymeric nanoparticles [48,49]. The $24 \mathrm{~h}$ release percentages of CTF were approximately $68.2 \pm 1.0 \%, 74.4 \pm 0.9 \%$ and $79.2 \pm 0.97 \%$ at $\mathrm{pH} 6.5,5.0$ and 4.5 , respectively. The initial burst displayed in the dissolution profile of CTF can be attributed to release of the surface-associated drug, while the long plateau phase is probably due to release of the encapsulated drug within the dense polymeric matrix [50]. PACTF showed a limited burst release at acidic conditions ( $\mathrm{pH} 6.5,5.0$ and 4.5), providing a gradual release for $18 \mathrm{~h}$ and a slow $6 \mathrm{~h}$ release phase, demonstrating better encapsulation of 5-FU within the core of the PACTF nanostructure. The $\mathrm{pH}$-sensitive behaviour of PACTF and CTF can be attributed to conformational changes that take place in response to variations in physiological $\mathrm{pH}$. At neutral conditions, CS remains stable/deprotonated, while at acidic conditions the protonation of the pendant amine groups causes the carriers to undergo gel-sol transitions, swelling and release of the encapsulated drug into the bathing liquid [51].

Kinetic modelling of the release data further characterised the dissolution of 5-FU from the nanocomplexes. The dialysis method is affected mainly by water imbibition, drug diffusion and polymer dissociation [52]. The exponent $n$ of the Korsmeyer-Peppas model provides valuable insight into the release mechanism as Fickian diffusion $(0.45 \leq n)$, non-Fickian (anomalous) diffusion $(0.45<n<0.89)$, case II transport $(n=0.89)$ or super case II transport $(n>0.89)$ [24]. Findings suggest that 5-FU encapsulated in CS based nano-formulations was retained, and released slowly over a prolonged period through a combination of diffusion and polymer erosion.

The MTT assay provided an estimation of cell viability centred on the principle that only metabolically active cells can convert MTT into a purple insoluble formazan product, while the SRB assay estimates cell number by staining TCA fixed cellular proteins with the pink aminoxanthine SRB dye [53]. Similar trends in cytotoxicity for both assays suggest a strong correlation between the two colorimetric assays. The PtAuCSBNps displayed no relevant in vitro cytotoxicity and even stimulated the growth of the HEK293 cells, suggesting good biocompatibility, with the CS moieties possibly serving as a nutrient source, similar to previous studies incorporating CS with nanoparticles 
conducted by our group [17,54]. Exposure to free 5-FU elicited a dose dependent decrement of cell survival to less than $45 \%$ in all cell lines, similar to previous reports [26,55,56]. Nanocomposites (PACTF and CTF) were well tolerated in the HEK293 cell line with more than 75\% maximum cell viability, but inflicted significantly greater damage to all cancer cell lines compared to the 5-FU at similar concentrations. The most profound antiproliferative effects were seen in the Caco-2 cells with up to $30 \%$ cell viability at the highest tested dosage. Similar results were obtained in our previous studies using these bimetallic nanoparticles to deliver doxorubicin [17], where the drug nanocomplexes exhibited high activity in the MCF-7 and Caco-2 cells at lower concentrations, as evidenced in the low $\mathrm{IC}_{50}$ values obtained. The doxorubicin nanocomplexes however were slightly larger than the 5-FU nanocomplexes in this study but were equally stable. Hence, a similar trend in the cytotoxicity profiles was obtained, suggesting that the PtAuBNps played a significant role in the cellular uptake and overall activity of the drugs in vitro. The $\mathrm{IC}_{50}$ values of PACTF and CTF for the Caco-2 cells were approximately $18.98 \mu \mathrm{g} / \mathrm{mL}$ and $21.99 \mu \mathrm{g} / \mathrm{mL}$ in MTT assay, and $19.25 \mu \mathrm{g} / \mathrm{mL}$ and $22.58 \mu \mathrm{g} / \mathrm{mL}$ in the SRB assay. In the HepG2 cell line, PACTF and CTF displayed slightly higher $\mathrm{IC}_{50}$ values, of approximately $22.85 \mu \mathrm{g} / \mathrm{mL}$, and $25.21 \mu \mathrm{g} / \mathrm{mL}$ in the MTT assay, and $23.10 \mu \mathrm{g} / \mathrm{mL}$ and $26.24 \mu \mathrm{g} / \mathrm{mL}$ in the SRB assay. PACTF and CTF were least effective in the MCF-7 cell line with high $\mathrm{IC}_{50}$ values of $29.73 \mu \mathrm{g} / \mathrm{mL}$ and $33.57 \mu \mathrm{g} / \mathrm{mL}$ in the MTT assay, and $30.12 \mu \mathrm{g} / \mathrm{mL}$ and $34.99 \mu \mathrm{g} / \mathrm{mL}$ in the SRB assay. The toxicity profiles obtained clearly support enhanced cytotoxicity after 5-FU loading. PACTF had the best anticancer activity in vitro in all cancer cell models, with excellent tolerance in the non-cancer HEK293 cell line. This can be attributed to the good stability (zeta potential of $30.5 \mathrm{mV}$ ) of PACTF favouring cellular uptake, its high 5-FU encapsulation ( $90 \%)$, and importantly its 5-FU release profile (Figure 5), which showed greater release of the drug (65-74\%) at lower pHs $(6.5,5.0,4.5)$, compared to the release $(\sim 20 \%)$ at physiological $\mathrm{pH}$ 7.4. Hence, 5-FU had a greater effect on the cancer cells than the non-cancer HEK293 cells. Hence, it can be inferred that the addition of PtAuBNps acted synergistically with 5-FU to enhance cytotoxicity, and were in consonance with the physiochemical characterisations and drug release profiles.

Programmed cell death or apoptosis is a regulatory mechanism for the removal of physiologically defective, unwanted, damaged or dysfunctional cells [57,58]. Cells undergoing apoptosis display distinct morphological features that include cytoplasmic shrinkage, chromatin condensation, loss of membrane phospholipid asymmetry, DNA fragmentation and membrane blebbing [57-60]. Acridine orange permeates all cells resulting in the emittance of green fluorescence, whereas ethidium bromide is only taken up by non-viable cells that have lost their cytoplasmic membrane integrity causing the nucleus to fluoresce red. The nucleus of viable cells emits a green fluorescence, early apoptotic cells with condensed or fragmented chromatin bright green, late apoptotic with condensed and fragmented chromatin yellow/orange and necrotic cells with no condensed chromatin orange/red [61]. Overall, the apoptosis studies corroborated well with growth inhibition (MTT and SRB assay), and drug release studies, with the drug nanocomplexes exhibiting a pH-sensitive release, especially PACTF which based on the kinetic modelling showed a steady release of the drug with no sudden burst release, and a zero-order release profile for enhanced therapeutic effects. This zero-order release profile also assists in determining the bioavailability of the drug, thereby enhancing the cellular uptake and treatment strategy [35]. The higher release at lower $\mathrm{pHs}$ may be significant in producing a system with greater activity in tumour micro-environments than under normal physiological conditions. This cancer cell targeting based on $\mathrm{pH}$ sensitivity may be further assisted by active receptor targeting the cancer cells, such as reported for folate targeting of 5-FU using polymerized gold nanoparticles [35].

The two metals, gold and platinum were combined to determine if the favourable properties of both metals would act synergistically producing a potentially efficient nanoparticle for drug delivery. This initial study was solely conducted in vitro and we are currently looking at further research using in vivo systems. On the positive side, this study did show some $\mathrm{pH}$ responsive behaviour of the nanocomplexes suggesting that they may target the cancer cells due to their low pH micro-environment. However, further studies and optimizations are required to produce a more definitive conclusion. This 
bimetalic system was shown to be promising, and being the first one reported for the delivery of 5-FU, it can be used to lay the foundation for future such research which may exceed the current strategy. Despite the vast array of existing systems, there is always a need for a more robust and stable delivery system. Future persepectives, can include the varying of the core-shell composition, use of alternate polymers such as polyethylene-glycol and poly(lactide-co-glycolide), and the introduction of targeting ligands for cancer cell specific delivery.

\section{Conclusions}

A novel, multifunctional, practical, customisable, stable, nanosized and pH-responsive PtAuCS bimetallic delivery system, exhibiting significantly higher anticancer potency than free 5-FU alone was established in this preclinical study. The embedding of PtAuBNps with CSNps acted synergistically with 5-FU to enhance its in vitro cytotoxicity, offering the prospects of reducing drug concentration and the frequency of dosage. Furthermore, this study strongly supports the notion that pH-triggered drug release brings about site-specific toxicity and enhances intracellular bioaccumulation of drugs, such as 5-FU that require metabolic activation to exert its cytotoxic effects. Overall, the PtAuCS bimetallic platform was shown to display superior optical properties, physiochemical features, pharmacokinetics, drug encapsulation, mucoadhesion and biocompatibility compared to the polymeric CSNps and the free 5-FU. These favourable physiochemical and biological attributes augur well for future in vivo and clinical applications, especially in the area of cancer therapy. Further studies would also involve the conjugation of a targeting moiety for cell specific delivery.

Supplementary Materials: The following are available online at http://www.mdpi.com/1999-4923/11/9/439/s1. Table S1: Pharmacokinetic parameters of PACTF under stimulated conditions. Table S2: Pharmacokinetic parameters of CTF under stimulated conditions.

Author Contributions: Conceptualization, Supervision, Project Administration and Funding Acquisition, M.S.; Methodology and Investigation, V.M. and M.S.; Writing-Original Draft Preparation: V.M. and M.S.; and Writing-Review and Editing, V.M. and M.S.

Funding: This research was partly funded by The National Research Foundation, South Africa, grant number $88195 / 81289$.

Conflicts of Interest: The authors declare no conflict of interest. The funders had no role in the design of the study; in the collection, analyses, or interpretation of data; in the writing of the manuscript, or in the decision to publish the results.

\section{References}

1. El-Hammadi, M.M.; Delgado, Á.V.; Melguizo, C.; Prados, J.C.; Arias, J.L. Folic acid-decorated and PEGylated PLGA nanoparticles for improving the antitumour activity of 5-fluorouracil. Int. J. Pharm. 2017, 516, 61-70. [CrossRef] [PubMed]

2. Kevadiya, B.D.; Patel, T.A.; Jhala, D.D.; Thumbar, R.P.; Brahmbhatt, H.; Pandya, M.P.; Rajkumar, S.; Jena, P.K.; Joshi, G.V.; Gadhia, P.K.; et al. Layered inorganic nanocomposites: A promising carrier for 5-fluorouracil (5-FU). Eur. J. Pharm. Biopharm. 2012, 81, 91-101. [CrossRef] [PubMed]

3. Rejinold, N.S.; Thomas, R.G.; Muthiah, M.; Lee, H.J.; Jeong, Y.Y.; Park, I.-K.; Jayakumar, R. Breast Tumor Targetable $\mathrm{Fe}_{3} \mathrm{O}_{4}$ Embedded Thermo-Responsive Nanoparticles for Radiofrequency Assisted Drug Delivery. J. Biomed. Nanotechnol. 2016, 12, 43-55. [CrossRef] [PubMed]

4. Reddy, A.B.; Manjula, B.; Jayaramudu, T.; Sadiku, E.; Babu, P.A.; Selvam, S.P. 5-Fluorouracil Loaded Chitosan-PVA/Na ${ }^{+}$. Nano-Micro Lett. 2016, 8, 260-269. [CrossRef] [PubMed]

5. Couvreur, P.; Patrick, C. Nanoparticles in drug delivery: Past, present and future. Adv. Drug Deliv. Rev. 2013, 65, 21-23. [CrossRef] [PubMed]

6. Lammers, T.; Kiessling, F.; Hennink, W.E.; Storm, G. Nanotheranostics and Image-Guided Drug Delivery: Current Concepts and Future Directions. Mol. Pharm. 2010, 7, 1899-1912. [CrossRef]

7. Arvizo, R.R.; Bhattacharyya, S.; Kudgus, R.A.; Giri, K.; Bhattacharya, R.; Mukherjee, P. Intrinsic Therapeutic Applications of Noble Metal Nanoparticles: Past, Present and Future. Chem. Soc. Rev. 2012, 41, 2943-2970. [CrossRef] [PubMed] 
8. Misra, R.; Acharya, S.; Sahoo, S.K. Cancer nanotechnology: application of nanotechnology in cancer therapy. Drug Discov. Today 2010, 15, 842-850. [CrossRef]

9. Buchtelova, H.; Dostalova, S.; Michalek, P.; Krizkova, S.; Strmiska, V.; Kopel, P.; Hynek, D.; Richtera, L.; Ridoskova, A.; Adam, P.; et al. Size-related cytotoxicological aspects of polyvinylpyrrolidone-capped platinum nanoparticles. Food Chem. Toxicol. 2017, 105, 337-346. [CrossRef]

10. Yamada, M.; Foote, M.; Prow, T.W. Therapeutic gold, silver, and platinum nanoparticles. Wiley Interdiscip. Rev. Nanomed. Nanobiotechnol. 2015, 7, 428-445. [CrossRef]

11. Liu, X.; Zhang, X.; Zhu, M.; Lin, G.; Liu, J.; Zhou, Z.; Tian, X.; Pan, Y. PEGylated Au@Pt Nanodendrites as Novel Theranostic Agents for Computed Tomography Imaging and Photothermal/Radiation Synergistic Therapy. ACS Appl. Mater. Interfaces 2016, 9, 279-285. [CrossRef] [PubMed]

12. Cheng, C.W.; Sie, E.J.; Liu, B.; Huan, C.H.A.; Sum, T.C.; Sun, H.D.; Fan, H.J. Surface plasmon enhanced band edge luminescence of $\mathrm{ZnO}$ nanorods by capping Au nanoparticles. Appl. Phys. Lett. 2010, 96, 071107. [CrossRef]

13. Kumar, A.; Vimal, A.; Kumar, A. Why Chitosan? From properties to perspective of mucosal drug delivery. Int. J. Boil. Macromol. 2016, 91, 615-622. [CrossRef]

14. Singla, A.; Chawla, M. Chitosan: some pharmaceutical and biological aspects-An update. J. Pharm. Pharmacol. 2001, 53, 1047-1067. [CrossRef]

15. Elgadir, M.; Uddin, M.; Ferdosh, S.; Adam, A.; Chowdhury, A.J.K.; Sarker, M.I.; Ferdous, S. Impact of chitosan composites and chitosan nanoparticle composites on various drug delivery systems: A review. J. Food Drug Anal. 2015, 23, 619-629. [CrossRef] [PubMed]

16. Chandran, P.R.; Sandhyarani, N. An electric field responsive drug delivery system based on chitosan-gold nanocomposites for site specific and controlled delivery of 5-fluorouracil. RSC Adv. 2014, 4, 44922-44929. [CrossRef]

17. Maney, V.; Singh, M. An in vitro assessment of novel chitosan/bimetallic PtAu nanocomposites as delivery vehicles for doxorubicin. Nanomedicine 2017, 12, 2625-2640. [CrossRef] [PubMed]

18. Huang, Y.; Rao, Y.; Chen, J.; Yang, V.C.; Liang, W. Polysorbate Cationic Synthetic Vesicle For Gene Delivery. J. Biomed. Mater. Res. Part A 2011, 96, 513-519. [CrossRef]

19. Zhang, H.; Toshima, N. Synthesis of Au/Pt bimetallic nanoparticles with a Pt-rich shell and their high catalytic activities for aerobic glucose oxidation. J. Colloid Interface Sci. 2013, 394, 166-176. [CrossRef]

20. Ekrami-Kakhki, M.S.; Khorasani-Motlagh, M.; Noroozifar, M. Platinum nanoparticles self-assembled onto chitosan membrane as anode for direct methanol fuel cell. J. Appl. Electrochem. 2001, 41, 527-534. [CrossRef]

21. Khalil, M.M.; Mostafa, Y.M.; Torad, E. Biosynthesis and characterization of Pt and Au-Pt nanoparticles and their photo catalytic degradation of methylene blue. Int. J. Adv. Res. 2014, 2, 694-703.

22. Singhvi, G.; Singh, M. Review: in-vitro drug release characterization models. Int. J. Pharm. Sci. Res. 2011, 2, 77-84.

23. Patel, N.; Chotai, N.; Patel, J.; Soni, T.; Desai, J.; Patel, R. Comparison of In Vitro Dissolution Profiles of Oxcarbazepine-HP b-CD Tablet Formulations with Marketed Oxcarbazepine Tablets. Dissolution Technol. 2008, 15, 28-34. [CrossRef]

24. Ramteke, K.; Dighe, P.; Kharat, A.; Patil, S. Mathematical models of drug dissolution: A review. Sch. Acad. J. Pharm. 2014, 3, 388-396.

25. Testa, G.; Fontana, L.; Venditti, I.; Fratoddi, I. Functionalized platinum nanoparticles with surface charge trigged by pH: synthesis, characterization and stability studies. Beilstein J. Nanotechnol. 2016, 7, 1822-1828. [CrossRef] [PubMed]

26. Nivethaa, E.A.K.; Dhanavel, S.; Vasu, C.A.; Narayanan, V.; Arumainathan, S. An in vitro cytotoxicity study of 5-fluorouracil encapsulated chitosan/gold nanocomposites towards MCF-7 cells. RSC Adv. 2015, 5, 1024-1032. [CrossRef]

27. Sanyakamdhorn, S.; Agudelo, D.; Tajmir-Riahi, H.-A. Encapsulation of Antitumor Drug Doxorubicin and Its Analogue by Chitosan Nanoparticles. Biomacromolecules 2013, 14, 557-563. [CrossRef]

28. Lawrie, G.; Keen, I.; Drew, B.; Chandler-Temple, A.; Rintoul, L.; Fredericks, P.; Grøndahl, L.; Lawrie, G. Interactions between Alginate and Chitosan Biopolymers Characterized Using FTIR and XPS. Biomacromolecules 2007, 8, 2533-2541. [CrossRef] 
29. Hou, J.; Yu, X.; Shen, Y.; Shi, Y.; Su, C.; Zhao, L. Triphenyl Phosphine-Functionalized Chitosan Nanoparticles Enhanced Antitumor Efficiency Through Targeted Delivery of Doxorubicin to Mitochondria. Nanoscale Res. Lett. 2017, 12, 415. [CrossRef]

30. Mohammadpour Dounighi, N.; Eskandari, R.; Avadi, M.; Zolfagharian, H.; Mir Mohammad Sadeghi, A.; Rezayat, M. Preparation and in vitro characterization of chitosan nanoparticles containing Mesobuthus eupeus scorpion venom as an antigen delivery system. J. Venom. Anim. Toxins Incl. Trop. Dis. 2012, 18, 44-52.

31. Akinyelu, J.; Singh, M. Chitosan Stabilized Gold-Folate-Poly(lactide-co-glycolide) Nanoplexes Facilitate Efficient Gene Delivery in Hepatic and Breast Cancer Cells. J. Nanosci. Nanotechnol. 2018, 18, 4478-4486. [CrossRef] [PubMed]

32. Doostmohammadi, A.; Monshi, A.; Salehi, R.; Fathi, M.; Karbasi, S.; Pieles, U.; Daniels, A. Preparation, chemistry and physical properties of bone-derived hydroxyapatite particles having a negative zeta potential. Mater. Chem. Phys. 2012, 132, 446-452. [CrossRef]

33. Chen, Z.; Zhang, C.; Tan, Y.; Zhou, T.; Ma, H.; Wan, C.; Lin, Y.; Li, K. Chitosan-functionalized gold nanoparti, cles for colorimetric detection of mercury ions based on chelation-induced aggregation. Microchim. Acta 2015, 182, 611-616. [CrossRef]

34. Boyles, M.S.P.; Kristl, T.; Andosch, A.; Zimmermann, M.; Tran, N.; Casals, E.; Himly, M.; Puntes, V.; Huber, C.G.; Lütz-Meindl, U.; et al. Chitosan functionalisation of gold nanoparticles encourages particle uptake and induces cytotoxicity and pro-inflammatory conditions in phagocytic cells, as well as enhancing particle interactions with serum components. J. Nanobiotechnol. 2015, 13, 293. [CrossRef] [PubMed]

35. Akinyelu, J.; Singh, M. Folate-tagged chitosan functionalised gold nanoparticles for enhanced delivery of 5-fluorouracil to cancer cells. Appl. Nanosci. 2019, 9, 7-17. [CrossRef]

36. Hung, S.-F.; Yu, Y.-C.; Suen, N.-T.; Tzeng, G.-Q.; Tung, C.-W.; Hsu, Y.-Y.; Chang, C.-K.; Chan, T.-S.; Sheu, H.-S.; Lee, J.-F.; et al. The synergistic effect of a well-defined Au@Pt core-shell nanostructure toward photocatalytic hydrogen generation: interface engineering to improve the Schottky barrier and hydrogen-evolved kinetics. Chem. Commun. 2016, 52, 1567-1570. [CrossRef] [PubMed]

37. Fan, F.-R.; Liu, D.-Y.; Wu, Y.-F.; Duan, S.; Xie, Z.-X.; Jiang, Z.-Y.; Tian, Z.-Q. Epitaxial Growth of Heterogeneous Metal Nanocrystals: From Gold Nano-octahedra to Palladium and Silver Nanocubes. J. Am. Chem. Soc. 2008, 130, 6949-6951. [CrossRef]

38. Thanachayanont, C.; Hilborn, J.; Sugunan, A.; Dutta, J. Heavy-metal ion sensors using chitosan-capped gold nanoparticles. Sci. Technol. Adv. Mater. 2005, 6, 335-340.

39. Guan, H.; Yu, J.; Chi, D. Label-free colorimetric sensing of melamine based on chitosan-stabilized gold nanoparticles probes. Food Control. 2013, 32, 35-41. [CrossRef]

40. Wang, J.; Tauchi, Y.; Deguchi, Y.; Morimoto, K.; Tabata, Y.; Ikada, Y. Positively charged gelatin microspheres as gastric mucoadhesive drug delivery system for eradication of H. pylori. Drug Deliv. 2000, 7, 237-243.

41. Nagarwal, R.C.; Kumar, R.; Pandit, J. Chitosan coated sodium alginate-chitosannanoparticles loaded with 5-FU for ocular delivery: In vitro characterization and in vivo study in rabbit eye. Eur. J. Pharm. Sci. 2012, 47, 678-685. [CrossRef] [PubMed]

42. Pilicheva, B.; Zagorchev, P.; Uzunova, Y.; Kassarova, M. Development and in vitro Evaluation of mucoadhesive microsphere carriers for intranasal delivery of betahistine dihydrochloride. Int. J. Drug Deliv. 2013, 5, 389.

43. Srivastava, G.; Walke, S.; Dhavale, D.; Gade, W.; Doshi, J.; Kumar, R.; Ravetkar, S.; Doshi, P. Tartrate/tripolyphosphate as co-crosslinker for water soluble chitosan used in protein antigens encapsulation. Int. J. Biol. Macromol. 2016, 91, 381-393. [CrossRef] [PubMed]

44. Du, J.-Z.; Mao, C.-Q.; Yuan, Y.-Y.; Yang, X.-Z.; Wang, J. Tumor extracellular acidity-activated nanoparticles as drug delivery systems for enhanced cancer therapy. Biotechnol. Adv. 2014, 32, 789-803. [CrossRef] [PubMed]

45. Yu, X.; Yang, X.; Horte, S.; Kizhakkedathu, J.N.; Brooks, D.E. A pH and thermosensitive choline phosphate-based delivery platform targeted to the acidic tumor microenvironment. Biomaterials 2014, 35, 278-286. [CrossRef] [PubMed]

46. Kamaly, N.; Yameen, B.; Wu, J.; Farokhzad, O.C. Degradable Controlled-Release Polymers and Polymeric Nanoparticles: Mechanisms of Controlling Drug Release. Chem. Rev. 2016, 116, 2602-2663. [CrossRef] [PubMed]

47. Kong, M.; Zuo, Y.; Wang, M.; Bai, X.; Feng, C.; Chen, X. Simply constructed chitosan nanocarriers with precise spatiotemporal control for efficient intracellular drug delivery. Carbohydr. Polym. 2017, 169, 341-350. [CrossRef] [PubMed] 
48. Dubey, R.R.; Parikh, R.H. Two-stage optimization process for formulation of chitosan microspheres. AAPS PharmSciTech 2004, 5, 20-28. [CrossRef] [PubMed]

49. Shi, L.; Tang, C.; Yin, C. Glycyrrhizin-modified O-carboxymethyl chitosan nanoparticles as drug vehicles targeting hepatocellular carcinoma. Biomaterials 2012, 33, 7594-7604. [CrossRef]

50. Rafiei, P.; Haddadi, A. Pharmacokinetic Consequences of PLGA Nanoparticles in Docetaxel Drug Delivery. Pharm. Nanotechnol. 2017, 5, 3-23. [CrossRef]

51. Islam, A.; Yasin, T. Controlled delivery of drug from $\mathrm{pH}$ sensitive chitosan/poly(vinyl alcohol)blend. Carbohydr. Polym. 2012, 88, 1055-1060. [CrossRef]

52. Streubel, A.; Siepmann, J.; Peppas, N.; Bodmeier, R. Bimodal drug release achieved with multi-layer matrix tablets: transport mechanisms and device design. J. Control. Release 2000, 69, 455-468. [CrossRef]

53. Keepers, Y.P.; Pizao, P.E.; Peters, G.J.; Van Ark-Otte, J.; Winograd, B.; Pinedo, H.M. Comparison of the sulforhodamine B protein and tetrazolium (MTT) assays for in vitro chemosensitivity testing. Eur. J. Cancer Clin. Oncol. 1991, 27, 897-900. [CrossRef]

54. Moodley, T.; Singh, M. Polymeric Mesoporous Silica Nanoparticles for Enhanced Delivery of 5-Fluorouracil In Vitro. Pharmaceutics 2019, 11, 288. [CrossRef] [PubMed]

55. Babaei, M.; Abnous, K.; Taghdisi, S.M.; Peivandi, M.T.; Alibolandi, M.; Farzad, S.A.; Ramezani, M. Synthesis of theranostic epithelial cell adhesion molecule targeted mesoporous silica nanoparticle with gold gatekeeper for hepatocellular carcinoma. Nanomedicine 2017, 12, 1261-1279. [CrossRef] [PubMed]

56. Sahu, P.; Kashaw, S.K.; Jain, S.; Sau, S.; Iyer, A.K. Assessment of penetration potential of pH responsive double walled biodegradable nanogels coated with eucalyptus oil for the controlled delivery of 5-fluorouracil: In vitro and ex vivo studies. J. Control. Release 2017, 253, 122-136. [CrossRef] [PubMed]

57. Liu, K.; Liu, P.-C.; Liu, R.; Wu, X. Dual AO/EB Staining to Detect Apoptosis in Osteosarcoma Cells Compared with Flow Cytometry. Med Sci. Monit. Basic Res. 2015, 21, 15-20.

58. Koff, J.L.; Ramachandiran, S.; Bernal-Mizrachi, L. A Time to Kill: Targeting Apoptosis in Cancer. Int. J. Mol. Sci. 2015, 16, 2942-2955. [CrossRef]

59. Ćurčić, M.G.; Stanković, M.S.; Mrkalić, E.M.; Matović, Z.D.; Banković, D.D.; Cvetković, D.M.; Đačić, D.S.; Marković, S.D. Antiproliferative and proapoptotic activities of methanolic extracts from Ligustrum vulgare L. as an individual treatment and in combination with palladium complex. Int. J. Mol. Sci. 2012, 13, 2521-2534. [CrossRef]

60. Fadok, V.A.; de Cathelineau, A.; Daleke, D.L.; Henson, P.M.; Bratton, D.L. Loss ofphospholipid asymmetry and surface exposure of phosphatidylserine is required for phagocytosis of apoptotic cells by macrophages and fibroblasts. J. Biol. Chem. 2001, 276, 1071-1077. [CrossRef]

61. Bezabeh, T.; Mowat, M.R.A.; Jarolim, L.; Greenberg, A.H.; Smith, I.C.P. Detection of drug-induced apoptosis and necrosis in human cervical carcinoma cells using 1H NMR spectroscopy. Cell Death Differ. 2001, 8, $219-224$. [CrossRef] [PubMed]

(C) 2019 by the authors. Licensee MDPI, Basel, Switzerland. This article is an open access article distributed under the terms and conditions of the Creative Commons Attribution (CC BY) license (http://creativecommons.org/licenses/by/4.0/). 